Mirjana Bojcevski ${ }^{1}$

Vlado Kovacevic ${ }^{2}$

Ministry of agriculture and environment

protection of the Republic of Serbia, Belgrade, Serbia

Jonel Subic ${ }^{3}$

Institut of agricultural economics, Belgrade, Serbia
SCIENTIFIC REVIEW ARTICLE doi:10.5937/ekonomika1603069B

Received: July11, 2016

Accepted: August 28, 2016

\title{
ROLL OF A FARM ACCOUNTANCY DATA NETWORKS (FADN) IN AGRICULTURAL SECTOR IN SERBIA
}

\begin{abstract}
The aim of this paper is to analyze the roll of the system of Farm accountancy data networks (FADN) in Serbian agriculture.

FADN system is compulsory for all EU Member States which are obliged to establish uniform system and FADN reports in standardized form are submitted annually to the European Commission. FADN reports are used by the EU institutions primarily for the purpose of analysis of agricultural policy measures.

FADN system is regulated by the European Union and it is based on annual survey on the structure, production, revenues and expenses of farms, with organizational structure of the FADN system and methodology prescribed by the EU.

The Republic of Serbia has started with the introduction of the FADN in 2011.

The analysis in this paper shows that the FADN system has importance regarding to fulfillment of the conditions necessary for EU integration. Additionally FADN has importance as instrument of domestic agrarian policy, importance for individual agricultural producers and importance for scientific research in the agricultural sector.
\end{abstract}

Keywords: FADN, accounting in agriculture, agrarian policy.

JEL classification: M410, M480

\section{ULOGA SISTEMA RAČUNOVODSTVENIH PODATAKA NA POLJOPRIVREDNIM GAZDINSTVIMA (FADN) U POLJOPRIVREDNOM SEKTORU SRBIJE}

\begin{abstract}
Apstrakt
Cilj rada je analiza uloge koju Sistem računovodstvenih podataka (FADN) ima u poljoprivrednom sektoru Srbije.

FADN je obavezan za sve zemlje članice EU koje su obavezne da uspostave sistem FADN i šalju standardizovane godišnje izveštahje Evropskoj Komisiji. FADN izveštaji se koriste od strane EU institucija primarno u cilju analize mera agrarne politike.
\end{abstract}

\footnotetext{
${ }^{1}$ mirjana.bojcevski@minpolj/gov.rs

2 vlado.kovacevic@minpolj.gov.rs

3 jonel_s@iep.bg.ac.rs
} 
Pravni okvir za FADN je definisan od strane EU i zasniva se na istraživanjima strukture, proizvodnje, prihoda, i troškova na poljoprivrednim gazdinstvima na godišnjem nivou prema organizacionoj strukturi i metodologiji koja je propisana za sve zemlje članice EU.

Republika Srbija je započela sa uvođenjem FADN sistema u 2011. godini.

Analiza u okviru ovog rada je pokazala da FADN sistem ima značaj u procesu priključenja Srbije EU s obzirom da je ovaj sistem obavezan za sve zemlje članice. Dodatno FADN sistem je važan instrument u kreiranju domaće agrarne politike, od važnosti je za pojedinačna poljoprivredna gazdinsta i naučno-istraživački rad u poljoprivrednom sektoru.

Ključne reči: FADN, poljoprivredno računovodstvo, poljoprivredna politika.

\section{Introduction}

All countries of the European Union through the FADN system collect technical, financial and economic data from over 80,000 agricultural holdings each year. The collected data includes all activities on farms during the twelve-month period. FADN survey is the tool by which the European Union is collected detailed financial data from agricultural holdings, and therefore represents an important source of information for decisions regarding agricultural policy (Hill B. \& Bradley D., 2016).

The requirements of the European Union related to the FADN survey are contained in the regulations of the European Commission, namely the Council Regulation (EC) No $1217 / 2009$ on establishing a system for the collection of accountancy data on incomes and business operation of agricultural holdings in the European Union (Council Regulation (EC) 1198 / 2014 amending this Regulation and Implementing Regulation (EU) No 220/2015 laying down rules for the application of Council Regulation (EC) No 1217/2009.

There are several requirements of the European Union in terms of the FADN methodology:

- links/relations with other statistical data and research,

- defining the representative sample/selection of farms,

- requirements for data collected and results,

- requirements in terms of data processing.

FADN research is closely related to the data collected by state institution for statistics, including agricultural census, a survey on the structure of agricultural holdings, calculate the standard value of production and the economic accounts for agriculture (Vasiljević \& Zakić, 2008).

FADN data can be distributed to different users:

- Participating institutions in FADN system (Ministry of Regional Coordination Mechanisms, Republic Institute for Statistics),

- agricultural producers,

- agricultural extension and technical services,

- educational and research institutions, agricultural and rural policies decision makers.

It is important to note that the FADN survey has strict regulations on the use of data than most other studies/surveys, due to the personal nature of each financial accounting 
report of the agricultural holding. Therefore, disseminating of the data must comply with restrictions on the use of the FADN data with clear procedures (Vasiljevic et al., 2012).

Dissemination of the FADN results is based on standard results, which are generated on the basis of validated forms of collective FADN accounting data farms. The standard results are a set of statistical data, calculated on the basis of accounting data patterns of agricultural holdings, which periodically prepares and publishes the European Commission ${ }^{4}$.

The European Commission also defines a method for performing the main variables of income and capital. All results are given in euros, enabling the results of the individual Member States can be given as the total value at EU level, and also enables the comparison of results of two or more Member States. Rate (national currency - the euro) is calculated for each Member State for each FADN accounting year, and an average of the monthly rates. These monthly exchange rates calculated by Eurostat and made available as part of the CRONOS database.

Organizational unit responsible for FADN in the European Commission has established a set of standard groups, for each accounting year is calculated standard results. This can be complemented by other relevant information available in the reference database. Variables defined in the standard results represent averages. These values are calculated for each year, per Member State, the type of farming and economic size class. Such information can be accessed from public databases, which offers the ability to view a large set of pictures of different 'average agricultural holdings across the European Union (Vasiljević, 2012).

Organizational unit responsible for FADN in the European Commission annually reviews the economics of agricultural holdings in the European Union on the basis of various economic and financial indicators. It also provides an overview of the situation on farms in the European Union and by Member State and by type of agricultural production over the past years. Reports on the development of revenue, the distribution of direct payments and less favored areas to perform agricultural production (marginal areas) are also regularly published. In addition to regular reports, the organizational unit responsible for FADN makes a special analysis. They require various units and directorates of the European Commission and other EU institutions, in particular the unit responsible for the management of agricultural markets, then for rural development, evaluation measures of the Common Agricultural Policy and policy making. Request for FADN data and ad hoc analyzes is constantly increasing (Pejanovic et al., 2013). Analyses based on the FADN research play a key role in the whole process of reforming the common agricultural policy, i.e. an evaluation of CAP measures and assessing the impact of policy proposals. Relevant reports can be found on the official website of the European Commission (Bradley D., 2015).

\section{Material and methods}

Having in mind the nature and significance of research, in the paper are used different methods applied in the social sciences:

- The case study method using the examples:

- Comparative method:

\footnotetext{
${ }^{4}$ See more: (RI/CC 882)- Definitions of Variables used in FADN standard results- RI/CC 882 Rev.9.2, December 2014
} 
- $\quad$ Desk research method:

- Method of interviews with relevant experts in the relevant field.

\section{Results and discussion}

FADN system in Serbia started in 2011, includes 33 agricultural extension stations distributed throughout the territory of the Republic of Serbia which are performing the work the Office for the collection of accountancy data for FADN survey. The data collected advisers employed in agricultural extension service, and Offices of collecting accounting data, who are responsible for the identification and location of agricultural producers for FADN research, data collection, processing and filling out forms and accounting entries with agricultural holdings in the FADN database.

The Ministry of Agriculture and Environmental Protection of Republic of Serbia and the National Committee for the FADN system determined the following criteria for the FADN field of research:

1) Two FADN regions - Serbia-North and Serbia-South,

2) The threshold of economic size of 4,000 euros,

3) 10 basic types of farms (out of 49);

4) 14 main groups of farms by economic size;

5) The representative number of holdings in the FADN sample will be approximately 2,000 households;

After established criteria for developing the plan for the selection for farms, second task was to establish FADN field of research and compiled a list of farms that are included in the plan (sorted by region, economic size and typology).

The selection of the FADN sample farms is based on data from official statistical farm register kept by Statistical office (based on Census of Agriculture from 2012 and other sources of information).

Organization of FADN system in the Republic of Serbia is involving: Statistics;

(1)The Ministry responsible for agriculture - Department for Analytics and

(2) The National Committee for the FADN system;

(3) Regional coordination bodies;

(4) The Republic organization in charge of statistics;

(5) Agricultural advisory and extension services;

(6) Agricultural holdings;

(7) Agricultural scientific, research and educational institutions.

The Ministry of Agriculture and Environment Protection is responsible for proposing systemic solutions in the field of agriculture, as well as for the implementation of Regulation (EC) No 1217/2009, which defines the organization and technical implementation of the FADN system. For effective functioning of the FADN system regional coordinating bodies are playing important roles by providing coordination of activities for the FADN system within its jurisdiction.

According to the Census of Agriculture, the Serbia has 631,552 farms, with 3,000 farms as a legal entities and entrepreneurs and 628,552 family farms. In 2013 the number of farms included in the FADN system was 500, while in 2014 and 2015, that number is increased to 1000 . 
FADN data in Serbia can be used for:

- Statistics and reports

- Analysis - data on demand, and research

- Extension officers,

- Feedback for agricultural producers.

FADN system generates annual reports and statistical analysis on the economic and financial situation in the agricultural sector. Due to the limited number of farms involved in the first years of establishing FADN research and verification of data quality, content and structure of the report needs time to be developed according to national requirements and needs (Keszthelyil et al., 2005).

The following charts shows examples of the possibilities and the importance of using data obtained from the FADN system ${ }^{5}$.

Figure 1. Land use by type of farming in 2013

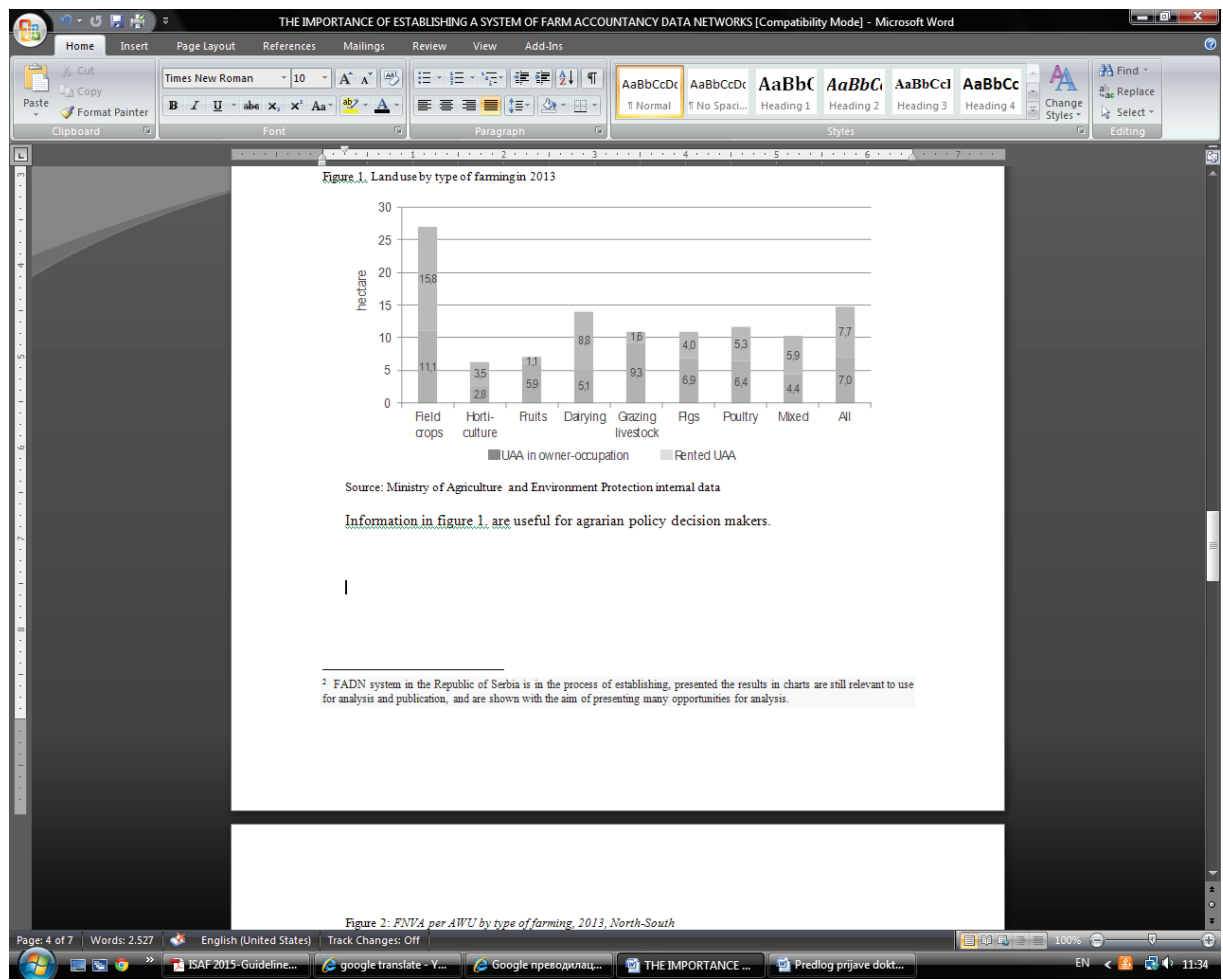

Source: Internal data of the Ministry of Agriculture and Environmenta Protection of the Republic of Serbia

Informations in Figure 1 are useful for agrarian policy decision makers.

${ }^{5}$ FADN system in the Republic of Serbia is in the process of establishing, presented the results in charts are still relevant to use for analysis and publication, and are shown with the aim of presenting many opportunities for analysis. 
Figure 2: FNVA per AWU by type of farming, 2013, North-South

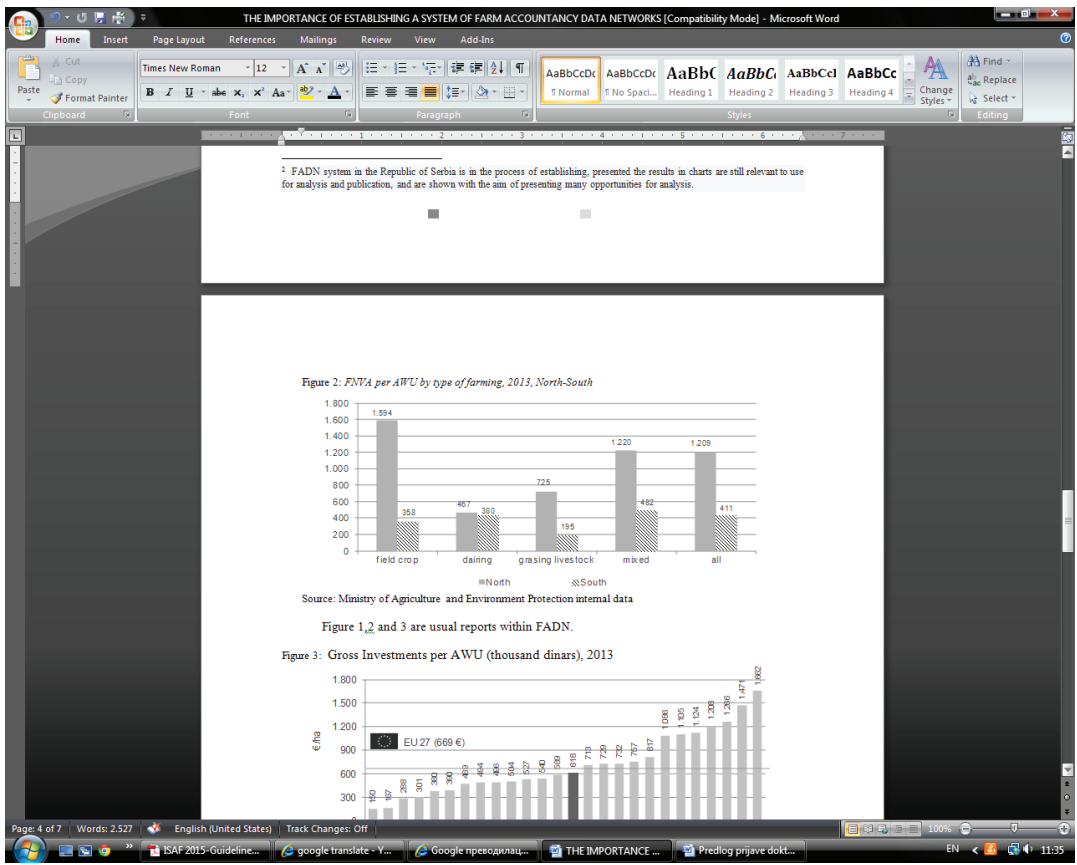

Source: Internal data of the Ministry of Agriculture and Environment Protection of the Republic of Serbia

Figures 1, 2 and 3 are usual reports within FADN.

Figure 3: Gross Investments per AWU (thousand dinars), 2013

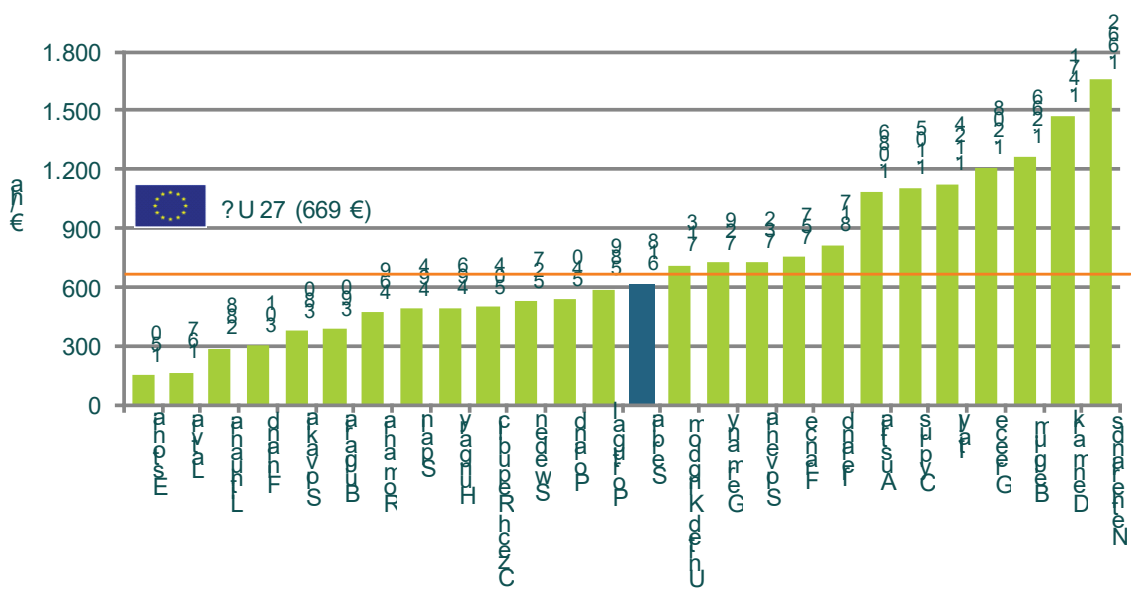

Source: Internal data of the Ministry of Agriculture and Environment Protection of the Republic of Serbia 
Roll of FADN data for scientific research. All collected statistical data are based on a predefined grouping of farms (type, size and region). In order to create benchmarks for individual farms, as well as specific analysis for the ministries and agricultural advisory services, it should be possible to request statistical data for agricultural holdings in other group sizes or a more detailed / more specific definition of the type of production. Such analysis or statistical data on demand should respect the confidentiality of the data, and present results only if at least five farms in the group (Barkaszi et al., 2009).

The importance of FADN data for agricultural advisory services. New information obtained from the FADN research improves the knowledge and improve operation of agricultural advisors. Statistical results and analysis of the national database (comparable to the EU, the region, the area etc.) can contribute to the enhanced analysis of individual agricultural holdings on the basis of which a counselor may make specific findings on the operations and allows them to provide better advice to farmers (Vasiljevic et al., 2008).

The importance of FADN feedback for agricultural producers. Agricultural producers are not obliged to make the bookkeeping in the Republic of Serbia and the FADN data are for the many farmers only relevant information on the operations of agricultural holdings. There are no binding requirements of the European Union to give feedback to the farmers on the operating results obtained in the FADN survey. However, it is considered an integral part of FADN good practice to perform feedback to the farmers. FADN feedback system is of great importance because the advisors can focus with its producers through record-keeping focus on revenue, expenses and profit (Csajbok et al., 2005).

\section{Conclusion}

During the coming year, the methodology of the FADN research will be further developed and adapted in accordance with the requirements of the European Commission, as well as institutions FADN system in the Republic of Serbia and the user information obtained on the basis of FADN research. Develop a methodology for FADN survey will also include the selection of agricultural holdings and on the collected data.

Additional modifications to the EU requirements and national requirements for FADN data in the Republic of Serbia could pose the new requirements regarding the information to be collected in the future. EU regulations establish minimum requirements in terms of data, and it requires regular monitoring and adjustment of the data should be processed and submitted to the European Commission.

In the coming period it is necessary to highlight national use of the data obtained in the FADN survey, the importance of using data for decision-making, which can on the basis of analysis of the impact of agricultural policy, promote the creation of measures of agricultural policy. Also, FADN data can provide to farmers information necessary for making business decisions, which should enable successful business and contribute to the achievement of profit.

It is important to monitor and respect all users FADN data and if there are specific national requirements necessary to include them in the FADN research, which will contribute to increasing the importance of the FADN system. The analyze in this paper shows that the FADN system in addition to the importance of having regard to fulfillment 
of the conditions necessary for EU integration has the importance for domestic agrarian policy, impact on improvement of the competitiveness of agricultural producers involved in the FADN and importance for scientific research in the agricultural sector.

\section{References}

Barkaszi L., Keszthelyi S., Kis Csatári E. \& Pesti C., (2009). FADN Accountancy Framework and Cost Definitions, The research leading to these results has received funding from the European Community's Seventh Framework Programme (FP7/2007-2013) under grant agreement no 212292, available at: http://facepa. slu.se/documents/Deliverable_D1-1-1_LEI.pdf, (accessed: 9.07.2016).

Bradley D., (2015). Cost of and good practices for FADN data collection-Final report, European Commission B-1049 Brussels, available at: http://www.ceasc. com/Images/Content/Cost $\% 20$ of $\% 20$ and $\% 20$ good $\% 20$ practice $\% 20 \mathrm{in} \% 20$ FADN\%20data\%20collection-\%20Final\%20report.pdf, (accessed: 5.06.2016).

Commission Delegated Regulation (EU) No 1198/2014 of 1 August 2014 supplementing Council Regulation (EC) No 1217/2009 setting up a network for the collection of accountancy data on the incomes and business operation of agricultural holdings in the European Union.

Commission Implementing Regulation (EU) 2015/220 of 3 February 2015 laying down rules for the application of Council Regulation (EC) No 1217/2009 setting up a network for the collection of accountancy data on the incomes and business operation of agricultural holdings in the European Union.

Commission implementing regulation (EU) 2015/2323 of 11 December 2015 amending Implementing Regulation (EU) 2015/220 laying down rules for the application of Council Regulation (EC) No 1217/2009.

Commission Regulation (EEC) No 1915/83 of 13 July 1983 on certain detailed implementing rules concerning the keeping of accounts for the purpose of determining the incomes of agricultural holdings.

Commission Regulation (EU) No 1291/2009 of 18 December 2009 concerning the selection of returning holdings for the purpose of determining incomes of agricultural holdings.

Council Regulation (EC) No 1217/2009 of 30 November 2009 setting up a network for the collection of accountancy data on the incomes and business operation of agricultural holdings in the European Community.

Csajbok I., Lansink A. \& Huirne R. (2005). Effects of management information from FADN on profitability of Dutch potted-plant firms, Agricultural Economics, 33 (3), p.p. 325-331.

EU Commission web page - FADN unit DGAGRI - http://ec.europa.eu/agriculture/ ricaprod/ (accessed: 08.08.2015).

EU Commission web page -http://eur-lex.europa.eu/homepage.html (accessed: 18.06.2015). 
Hill B. \& Bradley D. (2016). Comparative analysis of the FADN Data Collection Systems in EU-28, Paper prepared for presentation at the 90th Annual Conference of the Agricultural Economics Society, University of Warwick, England 4-6 April 2016, available at: http://www.aes.ac.uk/upload_area/member_documents/ Berkeley_Hill_Hill_Bradley_AES2016_FINAL.pdf, (accessed: 9.07.2016).

Keszthelyi1 K., Németh P. \& Pesti P. (2005). Analysis of Hungarian agricultural subsidies on the basis of FADN database, Paper prepared for presentation at the 99th seminar of the EAAE (European Association of Agricultural Economists), 'title', place, country, date as in: August 24-27, 2005. available at: http:// ageconsearch.umn.edu/bitstream/24689/1/pp05ke02.pdf, (accessed: 5.06.2016).

Pejanović, R., Vasiljević, Z., Tomić, V., Ljiljanić, N. \& Radišić, R. (2013), Problems in Record Keeping of Production and Economic Results of Family Farms in the Republic of Serbia, IV International Scientific Symposium "Agrosym 2013", Book of Proceedings, Faculty of Agriculture, University of East Sarajevo (B\&H), Jahorina October 3-6, 2013, (ISBN 978-99955-751-3-7), 10.7251/ AGSY13031181P, pp. 1181-1186.

Regulation (EU) No 1318/2013 of the European Parliament and of the Council of 22 October 2013 amending Council Regulation (EC) No 1217/2009 setting up a network for the collection of accountancy data on the incomes and business operation of agricultural holdings in the European Community.

Vasiljević Z. (2012). Uspostavljanje mreže računovodstvenih podataka na porodičnim poljoprivrednim gazdinstvima u Srbiji, u časopisu za pravo i ekonomiju evropskih integracija "Izazovi evropskih integracija", Tema broja "Poljoprivreda Srbije u procesu evropskih integracija", Broj 18. Izdavač Javno preduzeće Službeni glasnik uz podršku GIZ, Urednik Nikola Jovanović, ISSN 1820-9459, COBISS. SR-ID 1511881740, UDK 657:631.115.11, str. 27-40.

Vasiljević, Z. \& Zakić, V. (2008). Uvođenje knjigovodstva na individualna gazdinstva u funkciji lokalnog razvoja ruralne Srbije, Ekonomski vidici, Društvo ekonomista Beograda, XIII (2008), Br. 2, str. 447-460.

Vasiljević, Z., Ševarlić,M., Filipović N. \& Rahović, D. (2008). Uvođenje knjigovodstva na porodična poljoprivredna gazdinstva u Srbiji, u tematskom zborniku Evropska unija i Zapadni Balkan - Izazovi za agrarnu privredu Srbije: Šta nam je činiti, Regionalna privredna komora Novi Sad i DAES, Beograd, str. 57-72.

Vasiljevic, Z., Zaric, V., \&Ivkov, I. (2012). Recording of accountancy data at the family farms in Serbia. Third International Scientific Symposium "Agrosym Jahorina 2012". November 15-17, 2012, Jahorina, Faculty of Agriculture, ISBN 978-99955-751-0-6: COBISS.BH-ID 3336984: pp. 599-604. 